\title{
Being skeptical? Exploring far-right climate-change communication in Germany
}

\section{Abstract}

This article explores climate-change communication by the German far right - spanning a continuum which ranges from anti-liberal democracy radical-right populists, to the extreme right and to antidemocratic neo-Nazis - and asks: how do these actors articulate the phenomenon of climate change? In responding to this question, we conduct a discourse network analysis which identifies relations between actors, objects, phenomena and processes, and point out differences/similarities across a continuum of exemplary far-right sources. The investigated actors put forward a rather skeptical climate change narrative, even though differences exist as the significance attached to the Volk and its sovereignty, rooted in far-right ideology, sometimes overrides, and sometimes is in harmony with, their ideological-driven affinity with nature protection. We thus contribute to the growing body of knowledge on climate-change communication and, more specifically, on the link between ideology and climate-change skepticism.

\section{Introduction}

Whether or not the present is particularly crisis-ridden is open to debate, but our time hosts its fair share of crises. Besides the financial and economic crisis, environmental and political crises have come to populate the imagination of publics. The political crisis, a crisis of liberal democracy, is paradigmatically illustrated by the successes of far-right (non-)party actors across Europe while the environmental crisis (crises!) ranges from local and regional ones, e.g. water and air pollution, to global issues, especially climate change. Whilst these political and environmental crises have been analyzed extensively on their own, this article contributes to the analysis of their intersection, enquiring into communication about global climate change by particularistic far-right actors. Indeed, research on climate change has addressed the role of the liberal-left and conservative ideology (identifying conservative stances as rather skeptical), but the far right's views on climate change have not been scrutinized to a similar extent (but see Forchtner \& Kølvraa, 2015; Gemenis et al., 2012; 
Lockwood, 2018; Voss, 2014). This is despite the fact that both the re-emergence of these actors, ranging from anti-liberal democracy radical-right populists to extreme-right actors and antidemocratic neo-Nazis/fascists, and climate change are products of the rise of a world risk society (Beck, 1998): while climate change is a paradigmatic, unintended consequence of previous modernization, the contemporary success of the far right is, at least partly, a result of moving from first to second modernity, with its increased levels of uncertainty and the destabilization of identities.

Against this background, we ask: how is climate change articulated by the far right? More specifically, we explore differences/similarities across a continuum of exemplary sources, ranging from anti-liberal democracy radical-right populists to extreme-right and anti-democratic neo-Nazis. We do so conscious of potential tensions between ideological pillars in far-right thought: on the one hand, their ideologically-driven affinity for the natural environment visible in, e.g., their appreciation of what is supposedly authentic and stable (sometimes leading to a transfer of 'laws of nature' to the functioning of human relations; the supposed significance of the soil to the existence of the Volk [denoting, for the far right, an ethno-racial/cultural conception of 'the people']) and the perceived sacredness of the national landscape. On the other hand, this affinity has not always resulted in clear-cut pro-environment activities as other aspects, e.g. the focus on Volk and its sovereignty, have regularly subordinated environmental protection. The research question is thus about how ideology (differently) affect a variety of contemporary far-right actors in their climate-change communication. Instead of investigating parties (Forchtner \& Kølvraa, 2015; Gemenis et al., 2012; Voss, 2014), we focus on non-party actors which, in contrast to so-called far-right 'populist' parties acting more or less in the mainstream of their respective public spheres, can articulate their ideology in a fairly unconstrained manner. We do so by looking at a corpus compiled from German magazines and a blog (2007-2014), a sample which includes sources characterized by varying degrees of ideological rigor. The German case is telling, given, first, that "being green has emerged as a matter of national identity in Germany" (Uekötter, 2014, p. 2); second, the significance of the country's National Socialist past, both in official discourses and narratives of many far-right actors; and, third, the fact 
that forbearers of today's German far right have been involved in nature protection since the $19^{\text {th }}$ century.

The relevance of our contribution thus lies in complementing existing research on ideology in climate-change communication, in shedding light on the under-researched area of far-right climatechange communication, and in revealing differences/similarities within this political spectrum. While ways of conceptualizing ideology are notoriously manifold, including beliefs and representations shared by a social group as well as (false) ideas which facilitate the legitimation of power hierarchies, we adopt Seliger's (1976, p. 14) influential understanding of ideology as "a set of ideas by which men posit, explain and justify ends and means of organized social action", a belief system through which such action "preserve[s], amend[s], uproot[s] or rebuild[s] a given social order".

Our interest in the realization of far-right ideological features (see below) through climatechange communication happens against the background of research on climate skepticism which has mainly focused on conservative actors and their (nowadays often neoliberally 'enriched') ideology. After all, climate protection might pose a threat to the free market, individual freedom and national sovereignty due to (inter-)governmental regulation. Following Rahmstorf's (2004) differentiation, relevant studies have commonly separated trend skepticism (the denial of climate change happening at all) from attribution skepticism (the denial of climate change's anthropogenic cause) and impact skepticism (a changing climate might not be a bad thing). This typology has been expanded by van Rensburg (2015; see also Capstick \& Pidgeon, 2014), who speaks of evidence skepticism (covering Rahmstorf's three types), process skepticism (concerning knowledge generation and decision-making processes) and response skepticism (concerning policy responses) - a differentiation to which we will return in our analysis. The link between climate-change skepticism(s) and conservatism has been illustrated concerning, e.g., Australia, Germany, Sweden, the United Kingdom and the United States (Anshelm \& Hultman, 2014; Campbell \& Kay, 2014; Capstick \& Pidgeon, 2014; Carvalho, 2007; Jaspal, Nerlich \& van Vuuren, 2016; Kaiser \& Rhomberg, 2016; McCright \& Dunlap, 2011; Painter \& Gavin, 2016). At times, elements present in far-right climate-change communication resemble conservative contributions. However, they cannot be viewed as a sheer extension of them. Indeed, due to the 
connection between 'the people' (as Volk) and their natural environment in far-right thought and practice, skepticism towards a phenomenon which might ultimately have catastrophic effects on the national space does not 'naturally' align with these actors.

Following this introduction, we start exploring how a diverse set of far-right actors, against the background of their ideology, articulate climate change by briefly discuss definitional issues and present a history of how the German far right has related to the natural environment. We then introduce our data and methodology before turning to our analysis. We close with a summary of our argument, claiming that the investigated actors are largely (but not exclusively) climate-skeptic due to populist sentiment and/or fear over the continuance of the Volk being allegedly under pressure of 'globalist forces', and identify further avenues for research.

\section{Far-right actors - on the environment}

We analyze various actors who take different positions on a far-right continuum. Actors within this spectrum have been differently classified, including 'right-wing populist', 'radical right', 'extreme right' and 'right-wing extremist', and sometimes even '(neo-)fascist' (see Salzborn, 2014). This variety of designators is sometimes due to linguistic preferences, but also rooted in actual differences; farright populist parties such as the Danish People's Party (DPP) and the French Front National have increasingly moved towards an ever-evolving 'mainstream'; and thus, this group of anti-liberal, (nominally) democratic parties form one end of this continuum. Mudde (2007, pp. 22f) defines the core ideological features of these "populist radical right parties" as nativism, authoritarianism and populism. ${ }^{1}$ At the other end of this continuum, fascists/National Socialists are situated; actors whose nativism and authoritarianism (as well as, potentially, populism) results in a fully anti-democratic vision. In the following, we draw on a more specific conceptualisation, on a set of attitudes through

\footnotetext{
${ }^{1}$ Mudde (2007, p. 23) defines the last feature in terms of "society to be ultimately separated into two homogeneous and antagonistic groups, "the pure people" versus "the corrupt elite," and which argues that politics should be an expression of the volonté générale (general will) of the people".
} 
which actors along the far-right continuum "posit, explain and justify" their actions and imagine an ideal social order (Holzer, 1994; Salzborn, 2014, p. 19). Here, actors are characterised by völkisch thought (the community defined as an ethno-racial one, as an organic, collective subject), ethnocentrism and/or ethnopluralism, anti-pluralism, authoritarianism and a belief in the necessity of a strong state (the individual/citizen is subordinate to the community/state), anti-socialism, and a proclivity for scapegoating and a affirmable image of the in-group's historical past, e.g. signalled through backgrounding/denying the Holocaust. These criteria will be present to various degrees and, depending on the strength of their presence, actors are positioned on this continuum, from antiliberal democratic to outright anti-democratic. Thus, we do not sharply distinguish between the "populist radical right" (anti-liberal democracy), extreme-right actors and neo-Nazi anti-democrats, though neither do we deny that they are different.

Nature and the environment have always played a role in nationalist thought and for those concerned with Volk (for the following, see Forchtner \& Tominc, 2017; Geden, 1996; Olsen, 1999). Scholars of nationalism have rightly insisted on the crucial function of nature as connoting "that which rejects any suggestion of the contrived, of the consciously arranged" (Kedourie, 1966, p. 57); and specific sites, such as the British countryside or the German forest, have been central elements of the nationalist imagination. Smith $(2009$, p. 50) has consequently argued that nationalist communities have their "'ethno-scapes' in which a people and its homeland become increasingly symbiotic".

While there is thus a far-right perception of the environment, Germany is a paradigmatic case as environmental concerns and ecology thinking have long been interwoven with nationalist, völkisch, Social Darwinist and racist ideas (Geden, 1996; Olsen, 1999). According to Linse (2009, p. 158), the Heimatschutz movement (protection of the homeland) which emerged in the late $19^{\text {th }}$ century, resulting in the foundation of the Bund Heimatschutz (League for the Protection of the Homeland) in 1904, "[appears to have] always also been 'völkisch'”, even though it should not be considered a full part of this movement. Many Heimatschutz activists continued under National Socialism which "integrally linked" "Volk, racism and conservation" (Brüggemeier, Cioc \& Zeller, 
2005, p. 8; see also Uekötter, 2006). Until the mid-1930s, National Socialist's nature(-protection) rhetoric matched deeds, resulting in, e.g., the Reichsnaturschutzgesetz (Reich Nature Protection Law) of 1935 , the "most stringent and comprehensive environmental protection law" of its time (Lekan, 2004, p. 168). However, the goals of autarky, economic revival and war preparations collided with environmental concerns and led to continuous subordination of environmental concerns, e.g. when building dams and the Autobahn (Blackbourn, 2006, pp. 266-280; Dominick, 1992, pp. 81-118; Lekan 2004, pp. 204-251; Uekötter, 2006, pp. 30-43).

After 1945, far-right environmental communication did not vanish; individuals either found their way into relevant institutions (Franke \& Pfenning, 2014) or influenced the wider public in other ways. This tradition in green thought was analyzed in greater detail following (environmental) activities by the German far right during the 1970s, 1980s and early 1990s, including those of the party The Republicans and the Ecological-Democratic Party, as well as relevant magazines (Geden, 1996; Jahn \& Wehling, 1991; Olsen, 1999). Authors argue that the then ideological modernization of the far right was also related to increasingly 'legitimate' environmental concerns. This enabled the reproduction and dissemination of their traditional topics, e.g. 'race' (each 'race' has the right to separate itself in order to survive [ethnopluralism] and to remain connected to its soil), a strong state (the possibility of an eco-dictatorship), xenophobia (foreigners as an ecological problem) and population policy (a sustainable population policy). Since the 2000s, analyses have, e.g., focused on the extreme-right/neo-Nazi National Democratic Party of Germany (NPD) and its anti-genetically modified organism stance, the magazine Umwelt \& Aktiv (see below for details) and portrayals of völkisch settlers (HBS, 2012; PÖ, 2012). Hurd and Werther (2016), too, analyze materials by the NPD and Umwelt \& Aktiv, pointing out the significance of Heimat for the Volk. The authors (ibid., p. 164) argue that these actors' ecocriticism might be more fundamental than that of "the liberal tropes of 'sustainable development'”. These studies illustrate persistent concerns over the natural environment within the far right, a concern which should not be brushed aside because it does not conform with present-day, mainstream environmentalism. However, these studies neither cover climate-change communication nor how climate change relates to far-right ideology. 
Amongst relevant studies, Gemenis et al. (2012) focus on environmental themes in far-right environmental communications, including "Global warming is man-made": while their results concerning the NPD are "inconclusive" (so are those concerning the Swedish Democrats, SD), the Greek Popular Orthodox Rally is in agreement, while the British National Party (BNP), the DPP, the Italian Northern League (NL) and the Belgium Flemish Interest disagree. Forchtner and Kølvraa's (2015) study on the BNP and the DPP confirms these findings, while Voss $(2014: 163,165)$ views the DPP, NL, NPD and SD as agreeing with the thesis of man-made climate change. Most recently, Lockwood (2018) has explored the relationship between far-right actors and climate skepticism by elaborating on a threefold typology. Accordingly, this relationship is interest-based (the significance of the fossil-fuel industry), structural (neoliberal globalization has created 'left-behind' voters who feel most affected by climate policies) and/or ideological (being the paradigmatic cosmopolitan issue, climate change is rejected). Although conservatives and the far right do not belong to the same ideological family, these studies indicate parallels, e.g. concerning economic problems allegedly caused by climate policies and warnings against a disguised left-wing agenda. However, while much seems to suggest that the far right tends to be climate-skeptic, the results are not uniform. Therefore, more empirical research on far-right climate-change communication is needed, and thus we now turn to our data and mode of analysis.

\section{Data and methodology}

Our corpus comprises articles from far-right sources which differ in their ideological rigor, ranging from anti-liberal (nominally) democracy radical right populist to extreme-right actors and clearly antidemocratic neo-Nazis. These sources include the blog Politically Incorrect (PI) and the following magazines: Nation \& Europa (Nation \& Europe) and its follow-on project ZUERST! (FIRST!) (N\&E/Z!), Umwelt \& Aktiv (Environment \& Active; U\&A) and Recht \& Wahrheit (Law/Justice \& Truth; R\&W).

PI has existed since 2004 and is, basically, a one issue, anti-Islam blog which Hunger (2016, p. 428) referred to as "right-wing populist". The website features adverts for various far-right actors and, according to PI, has on average 150,000 visitors daily. The blog was thus chosen because of its 
wider prominence as well as its significance for the far-right spectrum (see also http://derstandard.at/2000037622930/Das-Gegenteil-von-Luegenpresse), but given the focus on Islam, we did not expect it to be a major contributor to the discourse on climate change. However, contrary to this assumption, a substantial number of posts addressed climate change.

Nation \& Europa (subtitle: "German monthly magazine [Monatshefte]") was one of the main extreme-right publications in Germany which Grumke and Wagner (2002, p. 455) described as "the most important theory-medium within German right-wing radicalism". Founded in 1951 (then Nation Europa) by a former major of the SS (Schutzstaffel), it appeared until 2009 and was published monthly. Authors included key members of the (inter)national far right. It was replaced in late 2009 by the monthly magazine ZUERST! (subtitle: "German news magazine") which attempts to transcend traditional extreme-right audiences.

The next publication we include also belongs to the extreme right, though it is of a very different type. U\&A (subtitle: “Magazine for holistic thinking. Environmental protection - animal protection - homeland protection") has been published quarterly since 2007 and is the extremeright, ecological publication in Germany. Close personal links to the NPD exist (HBS, 2012). Due to its professional focus on environmental issues, including nuclear energy, genetically modified organisms, gardening and (traditional) handicraft, as well as the history of ecological thinking and its far-right origins, it has attracted attention in and beyond the scene.

Of the investigated sources, R\&W (subtitle: "The sincere bimonthly magazine. Politics \& contemporary history from a German perspective") is farthest to the right, a neo-Nazi magazine which does not hide its orientation. It has been published since 1984 and, although at the fringes of the political spectrum, it is, like the other investigated magazines, relatively well produced magazine. It is a relevant actor, especially due to regularly staged reader meetings/congresses.

Our corpus consists of a sample of articles published by these sources between 2007 and 2014, thus covering a period of intense climate-change communication, especially around the 2009 hacking of the Climatic Research Unit at the University of East Anglia and the $15^{\text {th }}$ Conference of the Parties to the United Nations Framework Convention on Climate Change in Copenhagen, and wider 
societal turmoil in the course of the financial crisis. Selected articles must feature climate change (almost 90 per cent of the corpus) or conventional/alternative energy sources and the German energy transformation as semantic macro propositions. That is, "macro structures" through which language users understand and summarize texts, e.g. via a headline and/or lead paragraph (van Dijk, 1991, p. 131). ${ }^{2}$ In order to create a manageable and coherent corpus, we reduced the number of articles by considering only those which include Klimawandel (climate change), Klimaerwärmung (global warming), $\mathrm{CO}_{2}$, Wandel des Klimas (change of climate) or Erwärmung des Klimas (warming of the climate). ${ }^{3}$ The resulting corpus (Tab. 1) consists of coherent set of articles; and although PI dominates the corpus in terms of the number of articles, articles published by magazines are usually longer. And even in sources characterized by rather few codings ( $N \& E / Z$ ! and $R \& W)$, climate change is prominently present (Fig. 1).

$<$ FIGURE $1>$ HERE

Moving to the method of analysis, this study utilizes a discourse-analytical perspective. Following the topic-centered definition proposed by the discourse-historical approach (DHA) in critical discourse studies, we consider discourse to be a "cluster of context-dependent semiotic practices" which are "socially constituted and socially constitutive", "related to a macro-topic" (i.e. far-right contributions to the discourse on climate change) and involve arguments proposed by a variety of actors with

\footnotetext{
${ }^{2}$ While climate change and energy sources are obvious macro structures, energy transition towards renewables is also linked to climate change and, potentially, gives rise to climate-change skepticism (Engels, Hüther, Schäfer \& Held, 2013).

${ }^{3}$ The number of search words was limited as the four magazines are not digitally available. This hindered us, e.g., looking for Treibhausgase (Greenhouse gases), as we noticed early on that the latter was usually present next to " $\mathrm{CO}_{2}$ " or "climate change" /"global warming" (if it was present at all).
} 
different points of view (Reisigl \& Wodak, 2015, p. 27). Our investigation of contributions to the discourse about climate change by the far right is, however, not based on a qualitative, linguistic analysis in the tradition of the DHA, although we present examples throughout our discussion. Such examples offer both an understanding of the coded categories and of ways in which various claims and story elements are articulated. We argue that, in our case, examples are most beneficial if embedded in a quantitative approach, thus making visible the structure of far-right climate-change contributions to this discourse.

This is realized through a quantitative discourse network analysis (Discourse Network Analyzer, see http://www.philipleifeld.com/software/software.html) that enabled us to code not individual variables but relations between actors, objects, phenomena and processes. Such a relational perspective is beneficial as it does not primarily offer a look at a discrete category (e.g. "'The left'”, "Hysteria", "Greenhouse gases" etc.); instead, the object of study is the actual substance of discourses: relations between elements. The basic unit of analysis is the sentence (but not necessarily every sentence was coded), which was coded along the lines of Actant-Value-Actant (AVA). Actants can be actual actors, but also objects, phenomena and processes (e.g. "'The right", "Media", "Greenhouse gases", "Hysteria" and "Climate change"). We classified actants as precisely as possible, e.g. "UN", but if referents were multiple or unspecific, we condensed them in the actants “'The left"”/“'The right"” (Fig. 2).

The analysis proceeded by identifying a first actant (red circles in Fig. 2), e.g. "'The left", which stands in a value-relation (positive/affirmative [Yes]-negative/critical [No]) to a second actant (blue boxes in Fig. 2), e.g. "Common sense". For example, while discussing the metaphor of the greenhouse, authors in N\&E/Z! (02-2013, p. 11) cast doubt on the effects $\mathrm{CO}_{2}$ has on the climate: "However, although present, carbon dioxide in the atmosphere above desert areas therefore obviously causes no heat accumulation". This sentence was coded as "Greenhouse gases-NoClimate change". Positive and negative AVAs in each relation were then totalized and transformed into discourse network figures via UCINET in combination with a vector graphics editior (Fig. 2). Instead of combining numbers from the blog and the magazines, Figure 2 presents four discourse 
networks and therefore does not ignore differences between these actors (tentatively present due to the selection of sources). Sum total positive relations are represented as full lines, while sum total negative ones are dotted lines. Arrows indicate the direction of relation. Due to our sample with its differences in terms of article output and AVAs (Tab. 1), we pragmatically set a double threshold to improve this visualization and, more importantly, to carve out those relations which are particularly significant (though not in a statistical sense): first, only those relations are present in Figure 2 which account for at least 1 per cent of the total number of AVAs from the respective sources (rounded up/down). Second, all relations which emerge from this procedure must be present in at least 10 per cent of the number of articles published by the respective source (rounded up/down). For example, in the case of U\&A, only AVAs present at least ten times and across four articles were included in Figure 2.

$<$ TABLE 1> HERE

\section{Exploring far-right climate-change communication}

Let us start by looking at Figure 2 which summarizes our findings:

$<$ FIGURE 2> HERE

Numbers in Figure 2 represent the numbers of times respective AVAs were coded. Comparing these numbers across discourse networks is, however, hardly telling, as differences will often simply be due to differences in the total numbers of AVAs in the respective sources. However, some of these numbers are indicative. For example, "The left'-No-Common sense" has 266/90 AVAs in PI/U\&A, even though the total number of AVAs is $1,620 / 1,025$. In other words, this relation is more dominant, not only in absolute but also in relative terms, in the radical-right populist PI than in the extremeright, ecological U\&A. Thus, these numbers should primarily be considered within each of the four discourse networks or be compared in terms of their relative strength, i.e. their thickness (or 
existence), across networks. Although we cannot discuss all relations, we introduce central ones and exemplify them in the following.

We start with a look at general relations, first and foremost "'The left'-No-Common sense", a key relation across the four discourse networks. It consists of accusations against them, encompassing politicians to the left of the far-right in-group (thus regularly including members of the center-right Christian Democratic Party of Germany which is continuously disparaged), NGOs and unspecified others. They are misguided, are irrational and are simply not capable of recognizing the obvious. The following example illustrates this relation and a common polemical tone, especially in PI. Here, those worried about climate change and who have apparently identified those overweight as "climate-killers" are ridiculed: "[i]f also somewhere in the Caribbean a hurricane rampages or a well dries up in Africa, it was maybe exactly a load chips which served as the straw to break the camel's back" (http://www.pi-news.net/klimaschutz-dicke-als-klimakiller-ueberfuehrt/). While this article does not explicitly deny climate change, the piece adopts a polemical-skeptical tone, speaking of "medieval-collective delusions" and "inflamed climate change hysteria". In another contribution, anthropogenic climate change is explicitly denied as "climatic conditions change relentlessly" (N\&E/Z!, 04-2007, p. 6). Here, the author articulates “'The left'-No-Common sense” by claiming that “Renate Künast [then co-chair of the Green Party's parliamentary group] would recommend buying Japanese hybrid-cars, not German ones. A typical naïve fallacy. The expenditure on transport across the world's oceans results in minor benefits concerning mileage scupper" (ibid., p. 10). This example illustrates that not all statements can be discarded from an environmentalist point of view. Yet, even though shipping goods around the world is not environmentally friendly, even such comments are usually embedded in a polemical-skeptical frame, legitimizing othering. In this example, response skepticism (Rensburg 2015) is present; but so is evidence skepticism.

In turn, "The right'-Yes-Common sense" signifies the articulation of 'obvious' truths held by us, the in-group, as in cases of supposedly self-evident claims (at times using irony), and when referring to recent weather conditions along the lines of "It's freezing outside, where the hell is "global warming"??" (Donald T. Trump). 
Another relation featuring strongly in all discourse networks is "The left'-Yes-Misdeed". The latter goes beyond 'they don't get it' ("'The left'-No-Common sense") as it is claimed that they intentionally do wrong. In the case of $\mathrm{Pl}$, they are, e.g., accused of misdeeds due to their treatment of skeptics, claiming that "the whole carefully constructed mood of catastrophe" has led to the oppression of "serious [scientific] voices" and the creation of lists of "climate deniers" (http://www.pi-news.net/klima-wandel-skeptiker-werden-als-klima-leugner-gelistet/). The reference to "deniers" is delicate in Germany, though van Rensburg (2015) too, in an international context, has warned against use of the vocabulary of 'denialism', due to its connection to debates about the Holocaust, so as not to distort the debate. The other's alleged wrongdoing, mirroring conservative arguments (e.g. McKewon, 2012), furthermore includes, e.g., climate policies as money-spinning scams and theories of (left-wing) conspiracies. Frequently, these include the finance industry, though not always as clearly extreme right as in the following example taken from a text which was reprinted in $R \& W(09 / 10-2007$, p. 25):

Revolutions were conducted by parts of the elite, which understood to use the people [Volk], against the other part (...) To make the hardship of the final phase appear bearable for all involved, there is, among other things, "war on terror" and "climate catastrophe".

The focus on others' wrongdoing is, however, not restricted to an unspecific other ("'The left'”), but also visible in relation to, e.g., science as misleading the population. The fact that this negative relation is significant in all four discourse networks is interesting, as it already includes a high number of positive references to (inter)national climate-skeptic scientists. Figure 2 should thus not be read as articulating a rejection of science per se, but rather indicating a populist discontent with mainstream scientists who contribute to a political project by a corrupt elite, a project which harms the general will of the 'pure people' (Mudde, 2007: 22f). The othering of mainstream scientists is known from conservative skeptics who claim that mainstream scientists silence those not in agreement while celebrating skeptical scientists as, e.g., "'the people's scientists'” (McKewon, 2012, p. 284; see also 
Jaspal et al., 2016). Here again, it is not necessarily evidence skepticism which is present, but what van Rensburg (2015) refers to as process and response skepticism. Further examples along these lines include allegedly non-transparent procedures characterizing decisions by the Intergovernmental Panel on Climate Change and the use of computer models. An article in PI (http://www.pinews.net/pazifik-zu-kuhl-klima-wird-einfach-nicht-heis/) speaks of "climate swindlers" and "climate swindle", and approvingly quotes a mainstream source: "[t]he climate has not heated any further for 15 years, the curve does not point up - although humanity increasingly blows carbon dioxide into the atmosphere. (...) So far, computer models cannot explain the development... ."

We assume that one motivation underlying criticism of climate policies is that facing up to climate change can diminish sovereignty and enforce 'the globalist regime' with all its supposedly dangerous consequences for the Volk. Very frequently, we furthermore encounter warnings familiar from conservative sources concerning the harm done by these policies to the economy, while another motivation is more populist and juxtaposes 'the pure people' with a corrupt/ing elite (Mudde, 2007). In fact, the final relation present across all sources introduced now, concerns the left's alleged hostility towards ordinary people, 'the little guy'. The latter has become a victim of the liberal elite which looks down on her/him and financially disadvantages her/him through, e.g., rising energy prices. This is indeed a key trope, pointed out not only in other studies on the far right (e.g. Lockwood, 2018), but is also visible in conservative climate skepticism (Jacques et al., 2008). In a typical manner, PI (http://www.pi-news.net/132025/) claims that politicians want to "squeeze umpteen billions out of the tax-citizen for non-occurring climate warming". As such, even in sources which articulate (significant) concerns for the environment, climate-skeptic positions can thus be present and contradict environmentally-friendly policies.

Concerning particular others, and apart from U\&A, the actants "Media", "UN", "EU" and "USA" harm us ("...-Yes-Misdeed"). One example is taken from the neo-Nazi R\&W (04-2011, p.12) which attacks the abolition of nuclear energy in Germany, a claim not in itself problematic as a few mainstream environmentalists have taken a similar stance, by describing the media ("Media") as being "synchronized [gleichgeschaltet]" (the process via which Nazis established control over 
German society) in favor of the climate and against $\mathrm{CO}_{2}$ (speaking of a "fictional climate catastrophe"), and by saying that "[a]s Germany is allegedly the world's biggest export country, the destruction of tested and ensured energy supplies would be a considerable success for American foreign policy". Indeed, the frequent othering of the media has also been noted by Capstick and Pidgeon (2014) and McCright and Dunlap (2011) long before the contemporary popularity of attacks on 'fake-news'.

Accusing them of being uncritical is also present in another relation in $\mathrm{PI}, \mathrm{N} \& \mathrm{E} / \mathrm{Z}$ ! and $\mathrm{R} \& \mathrm{~W}$, but not in U\&A: “The left'-Yes-Climate change religion". The former three represent "The left" as engaging in a blind and zealous, quasi-religious belief in climate change. This too is a well-known trope often present in conservative climate skepticism as, e.g., Jaspal et al. (2016), Anselm and Hultman (2014) and McKewon (2012) have argued.

A further relation key in $\mathrm{PI}, \mathrm{N} \& \mathrm{E} / \mathrm{Z}$ ! and $\mathrm{R} \& \mathrm{~W}$, but not in U\&A, concerns the left's alleged opposition to both individual and collective freedom. A concern for the former is especially present in PI and linked to compulsory actions and charges; for example, even citizens "who do not want to refuel 'ecologically' are having a (dubious) benefit forced upon them [zwangsbeglückt] via an admixture from the state" (https://www.pi-news.net/un-bericht-bio-kraftstoff-schlecht-fuer-dieumwelt/). This post does not doubt climate change per se, but it articulates a (polemical) critique based on environmental consequences caused by producing biofuels. Regularly, such arguments parallel those by conservative skeptics characterized by what Campbell and Kay (2014) refer to as 'solution aversion', e.g. fear over the economic impact of climate policies, as well as accusations along the lines of 'Green is the new red' (McKewon, 2012). PI also plays to the aforementioned tune of 'the elite' controlling individuals and restricting their lifestyle and even suggests the emergence of an eco-dictatorship, the totalitarian character of "ecologism" and a planned economy ("ClimateSoviet", http://www.pi-news.net/klima-gutmenschen/).

Expanding on a collective notion of (un)freedom, the idea of sovereignty becomes central, a concept connected to autarky which is supposed to guarantee the nation's freedom (Fig. 3). Indeed, and as Smith (1991, p. 77) notes, "[a]utonomy is the goal of every nationalist." 
$<$ FIGURE 3> HERE

Concerns over the rise of a 'one-world' regime are thus prominent, and one reason why the very existence of man-made climate change is sometimes viewed skeptically. In other words, climate change is allegedly legitimizing a regime which aims not simply at the dissolution of national spaces, but at the reproduction of specific, global hegemonies. A drastic example of "The left'-No-Freedom" - not explicitly doubting the relevance of $\mathrm{CO}_{2}$ - is taken from a lengthy contribution to $\mathrm{R} \& \mathrm{~W}(01 / 02-$ 2011, p. 20), which deals with biofuels and, among other things, links the latter to national sovereignty:

All suggestions, proposals and claims concerning the construction of hydrogenation plants as a possibility to sustain German mining and to, simultaneously, become independent of oiland coal-imports, were already back than [after World War Two] being rejected (...) Why? Exactly, so that high finance earns. Whom do these politicians serve?

What is interesting to note is the anti-Semitic trope of "high finance" and the idea of a political elite controlled by others, and the prior celebration of "scientific top outputs, inventions and patents" produced before 1945 as enabling the nation's freedom, but which were curtailed by the Allies (see below for more references to Nazism).

Concerning N\&E/Z! and especially U\&A, but not PI and R\&W, the presence of "'The right'Yes-Environment" is notable. While these actors show significant concern for the "Environment", the latter is also used to other "'The left"” ("The left'-No-Environment", also in R\&W). However, such an environmentally friendly stance does not necessarily affect climate-change communication as seen in N\&E/Z! (04-2007, p. 5): “[e]specially for patriots, nature and environmental protection has the highest priority. Who loves his people [Volk], will not want to see its habitat [Lebensraum] being poisoned and destroyed. However, hysteria is a bad adviser in all areas". The accusation of being 
hysteric ("Hysteria" being an actant present in PI, N\&E/Z! and R\&W) is not in itself necessarily linked to evidence skepticism, but it is this hysteria which feeds into skepticism regarding anthropogenic climate change. In contrast, a former politician in the no longer existing, far-right party German People's Union, Sojka (U\&A, 01-2008, p. 18), goes beyond such a stance, discussing critically the failure to reach an international agreement on limiting $\mathrm{CO}_{2}$ (and other greenhouse gases), before saying that "[i]t is thus time to bring back again (...) the nurturing and conservation of our planet to the responsibility of citizens who view ecology as one of the most important life's tasks [Lebensaufgaben] and act accordingly".

U\&A and R\&W explicitly view alternative energy sources ("EnAlt") as contradicting common sense, having sinister consequences or even harming the environment. The latter relation contains different foci, including legitimate concerns, such as the death of birds in wind turbines and the consequences of the biofuels boom for biodiversity. While these arguments are often presented polemically, especially U\&A offers a seriously ecological position, being the only actor combining "The right'-Yes-Environment" with “'The right'-Yes-EnAlt”. For example, Roßmüller (2007, p. 10), currently member of the NPD party executive, argues against nuclear energy and in favor of renewable energy sources (also due to the former's poor $\mathrm{CO}_{2}$ footprint), a transformation which will furthermore enable "a structural change towards widely scattered decentral facilities in accordance with the principle of spatially oriented economics ["raumorientierten Volkswirtschaft"]". The latter concept connects far-right ideology (an economy not relying on a logic of global capitalism but rooted in communities) to climate-change communication.

Although Howanietz (U\&A, 01-2011, p. 16), who has worked for and with the current leadership of the Freedom Party of Austria, too affirms alternative energy sources, his stance is linked to evidence skepticism concerning the anthropogenic origins of climate change. Speaking of the benefits of solar energy, he states that the "'cult' [of energy autonomy] is thus much more than zeitgeisty idolatry of the ghost of a, in its circulated anthropogenic origin, dubious climate change".

As Figure 2 shows, articles in $\mathrm{PI}, \mathrm{N} \& \mathrm{E} / \mathrm{Z}$ ! and $\mathrm{R} \& \mathrm{~W}$ regularly voice such evidence skepticism by denying the effect of anthropogenic greenhouse gases ("Greenhouse gases-No-Climate change"). 
Even in cases where $\mathrm{CO}_{2}$ is allowed to play a role, e.g. when reference is made to the natural production of $\mathrm{CO}_{2}$ through volcanism, human activity is thus backgrounded. At one point, $\mathrm{PI}$ (https://www.pi-news.net/klimawissenschaftler-es-ist-nicht-das-co2/) affirmatively reprints an article by an Australian climate-skeptic which acknowledges that temperatures rose between 1975 and 2001, but ultimately claims that "there is no proof from anybody that this was due to $\mathrm{CO}_{2}$ emissions". Similarly, N\&E/Z! (01-2008, p. 44) speaks of "'climate catastrophe'” (in quotation marks), after having claimed that "[o]bviously uncontrollable elemental forces are at work" (ibid., p. 40). And R\&W (07/08-2007, p. 13) reasons:

There have been countless warmings and coolings of the earth's atmosphere over the course of the earth's history, ice ages and warm stages. During no change in the climate did $\mathrm{CO}_{2}$ play a noticeable role, in all cases, it was the sun or continental drift which was the cause.

Many articles claim that temperatures were higher in the past, while the concentration of $\mathrm{CO}_{2}$ in the atmosphere was not, thus implying that anthropogenic $\mathrm{CO}_{2}$ emissions have no influence. Such statements are often linked to examples, e.g. viticulture in Britain. Linked to skepticism concerning the influence of human activity on the climate are claims concerning actual benefits that $\mathrm{CO}_{2}$ has for plants (especially in N\&E/Z!). Far from being detrimental, $\mathrm{CO}_{2}$ is framed as nothing to worry about as it is a molecule essential to the well-being of plants.

However, anthropogenic climate change is not denied by everyone. Even though this does not include an affirmation of mainstream assumptions and policies linked to climate change, especially U\&A does not engage in continuous evidence skepticism. Sojka (U\&A, 01-2008, p. 16), e.g., considers the effects of $\mathrm{CO}_{2}$ emissions from an ecological perspective, stating that "[t]his harmony becomes muddled by humans, so that earth's climate system increasingly topples". Apart from whether or not ecological systems can be in "harmony" (or 'equilibrium'), what matters here is that a concern over climate change is located within an anti-globalist environmentalism. Sojka thus tells a 
story in which key elements of far-right thought - anti-globalism and a concern for the natural environment - are combined.

Interwoven in these actor's climate-change communication are references to National Socialism. For example, N\&E/Z! (04-2007, p. 6) notes that "in the middle of world war turmoil, 1943, the 'Völkische Beobachter' informed with a big effort about climate change, albeit cool and factual, without adventurous accusation of guilt". Indeed, N\&E/Z! reprinted this article by the newspaper of the Nazi party, while R\&W refers more than once to paragraph 130 of the German Penal Code ('incitement to hatred'), a paragraph which also covers Holocaust denial. In one case, R\&W (2009, p. 36) claims:

As long as paragraph 130 of the Penal Code is not extended to cover denial of the greenhouse effect, I can only say: given all known and comprehensible facts, it is a lie, which was begotten in order to talk uninformed humans into feelings of guilt and to squeeze money from their pockets.

Finally, we were surprised about a lack of climate-change skepticism connected to migration. Although present in some instances, a concern for "Climate refugees" was not crucial between 2007 and 2014. This is probably because climate refugees were not a widely discussed topic in the public domain, though future research will have to look closely at how this emerging subject position is treated by the far right.

\section{Conclusion}

In this article, we have explored contributions to the discourse about climate change. More precisely, we have analyzed far-right sources along the far-right continuum by conducting a discourse network analysis: the radical-right populist blog PI, the extreme-right magazines N\&E/Z! and U\&A, and the neo-Nazi magazine R\&W. This approach enables a relational, quantified view of far-right meaningmaking. However, its time-consuming nature makes it rather unsuitable for larger corpora and it 
does not provide details of the actual stories circulating in these networks. We thus also presented examples of these relations to shed further light on this rarely discussed communication. Our analysis illustrates that, although concerns over the natural environment are at the heart of far-right ideology, various ways of articulating climate-change skepticism are present. While such a position held by anti-liberal democracy radical-right populists might be due to a less 'rigorous' far-right ideological stance, even rather ideologically 'pure' actors (N\&E/Z! and R\&W) are not convinced by anthropogenic climate change and reject mainstream diagnoses and reactions.

As we have highlighted, many tropes in far-right climate-change communication are familiar from research on conservative climate-change skepticism. These include criticism of mainstream scientists and the media as distorting climate-change communication; accusations against the mainstream as being alarmist and close to a religious cult; attacks against climate policies as being money-making scams; and the rejection of such policies as causing economic harm. While it is not surprising that such overlaps between ideological camps exist, we do not imply that these two camps are one. Instead of an individualistic cultural world view, which drives conservative skepticism (Capstick \& Pidgeon, 2014), the key aspect in far-right thinking is collectivist, i.e. a concern with the Volk, its sovereignty and well-being coming under threat from globalist climate policies. Future studies should investigate, in detail, the structure of arguments shared by conservative and far-right sources, thus illuminating this overlap.

Our discussion illustrates that various forms of skepticism are present in far-right climatechange communication, including process and response skepticism next to evidence skepticism (van Rensburg, 2015). Future studies thus need to cover the various ways in which far-right actors are skeptical by going beyond a focus on evidence skepticism. After all, all types of skepticism help to position actors and connect far-right stances to these actors' wider ideology, i.e. ideas through which activity is structured and an ideal social order is imagined. Imagining the threat of 'globalism', e.g., can be linked to völkisch and ethnopluralist stances, as the former is viewed as threatening the community's capacity to reproduce itself as it wishes. There are, furthermore, concerns over the ability of the (German) state to remain strong, although the vision of an eco-dictatorship is not 
present (in contrast to earlier far-right environmental communication). The anti-socialist stance of these actors is explicitly present in warnings against climate policies as a means employed by the left to strengthen its agenda. Furthermore, there is little decentredness in these contributions; othering and scapegoating are found in abundance (though U\&A also provides more reflective pieces). As such, anti-pluralism is a common feature since, e.g., the political 'opponent' is vigorously attacked. Finally, references to World War Two are embedded in climate-change communication, especially by those at the extreme end of the far-right continuum. While this study confirms a previously identified trend of far-right parties as being rather climate-change-skeptic due to ideological factors (Forchtner \& Kølvraa, 2015; Lockwood, 2018), we have illustrated that this is not uniformly so.

Although Voss' (2014) argument, that the more to the right an actor is, the more likely s/he is to protect nature, is plausible, it is thus necessary to consider further factors in future studies, e.g. the respective party system and political opportunity structure, the media landscape and the historical salience and specificities that environmental issues carry in particular contexts. Finally, studies need to look at different genres in which climate change is communicated: while we have investigated non-party publications, these findings need to be triangulated with analyses of party magazines, manifestos and programmes (Forchtner \& Kølvraa, 2015) as well as parliamentary activities (Voss, 2014) by different types of far-right actors. All this, however, does not suggest the insignificance of the dimension of ideological rigor. The case of U\&A illustrates a refined position by an extreme-right actor who offers arguments in favor of and against anthropogenic climate change within a substantive, ecological agenda.

Contemporary successes of far-right actors call for a comprehensive understanding of their activities. Why and in what contexts are some skeptical, while others are not? What stories about climate change do these actors propose and how are they linguistically conveyed? We have explored and provided some answers, but whether far-right actors are skeptics or not, their climate-change communication constitutes responses to, returning to Beck's theory of risk mentioned at the beginning, the rise of an increasingly fluid world. Indeed, the far right, with its aim of naturalizing social relations, is a paradigmatic actor working in favor of ontological security by connecting stories 
which strengthen essentialist identities and facilitate clear boundaries to the discourse about climate change. As such, these ideas should not be ridiculed, but attempted to be understood within their wider (ideological) context.

\section{References}

Anshelm, J. \& Hultman, M. (2014). A green fatwā? Climate change as a threat to the masculinity of industrial modernity. NORMA: International Journal for Masculinity Studies, 9(2), 84-96.

Beck, U. (1998). World Risk Society. Polity Press.

Blackbourn, D. (2006). The Conquest of Nature. Water, Landscape and the Making of Modern Germany. Vintage.

Brüggemeier, F.-J., Mark C., \& Thomas Z. (Eds) (2005). How Green Were the Nazis? Nature, Environment, and Nation in the Third Reich. Ohio University Press.

Campbell, T. H. \& Kay, A. C. (2014): Solution aversion: on the relation between ideology and motivated disbelief. Journal of Personality and Social Psychology, 107(5), 809-824.

Capstick, S. B. \& Pidgeon, N. F. (2014): What is climate change scepticism? Examination of the concept using a mixed methods study of the UK public, Global Environmental Change, 24, 389401.

Carvalho, A. (2007). Ideological cultures and media discourses on scientific knowledge: re-reading news on climate change. Public Understanding of Science, 16(2), 223-243.

Dominick, R. H. (1992). The Environmental Movement in Germany. Prophets and Pioneers, 18711971. Indiana University Press.

Engels, A., Hüther, O., Schäfer, M. \& Held, H. (2013): Public climate-change skepticism, energy preferences and political participation. Global Environmental Change, 23, 1018-1027.

Forchtner, B. \& Kølvraa, C. (2015). The Nature of Nationalism: Populist Radical Right Parties on Countryside and Climate. Nature and Culture, 10(2), 199-224.

Forchtner, B. \& Tominc, A. (2017): Kalashnikov and cooking-spoon: neo-Nazism, veganism and a lifestyle cooking show on YouTube. Food, Culture and Society, 20(3), 415-441. 
Franke, N. M. \& Pfenning, U. (Eds). (2014). Kontinuitäten im Naturschutz. Nomos.

Geden, O. (1996). Rechte Ökologie. Umweltschutz zwischen Emanzipation und Faschismus. Elefanten.

Gemenis, K., Katsanidou, A. and Vasilopoulou, S. (2012). The politics of anti-environmentalism: positional issue framing by the European radical right. Paper prepared for the MPSA Annual Conference, 12-15 April 2012, Chicago.

Grumke, T. \& Wagner, B. (2002). Handbuch Rechtsradikalismus. Personen - Organisationen Netzwerke vom Neonazismus bis in die Mitte der Gesellschaft. Leske+Budrich.

HBS (2012). Braune Ökologen. Hintergründe und Strukturen am Beispiel Mecklenburg-Vorpommerns. Heinrich-Böll-Stiftung MV.

Holzer, W. I. (1994). Rechtsextremismus - Konturen, Definitionsmerkmale und Erklärungsansätze. In: Dokumentationsarchiv des österreichischen Widerstands (Ed.), Handbuch des österreichischen Rechtsextremismus. Aktualisierte und erweiterte Neuausgabe (pp. 12-96). Deuticke.

Hunger, A. (2016). Gut vernetzt - Der Kopp-Verlag und die schillernde rechte Publizistenszene. In: S. Braun, A. Geisler and M. Gerster (Eds), Strategien der extremen Rechten (pp. 425-438). VS.

Hurd, M. \& Werther, S. (2016): The militant media of neo-Nazi environmentalism. In: G. Heike (Ed.). The Environment in the Age of the Internet. Activists, Communication and the Digital Landscape (pp. 137-170). Open Book Publishers.

Jahn, T. \& Wehling, P. (1991). Ökologie von rechts. Campus.

Jaspal, R., Nerlich, B. \& van Vuuren, K. (2016). Embracing and resisting climate identities in the Australian press: sceptics, scientists and politics. Public Understanding of Science, 25(7), 807824.

Kaiser, J. \& Rhomberg, M. (2016). Questioning the doubt: climate skepticism in German newspaper reporting on COP17. Environmental Communication, 10(5), 556-574.

Kedourie, E. (1966). Nationalism. Hutchinson.

Lekan, T. M. (2004). Imagining the Nation in Nature. Landscape Preservation and German Identity 1885-1945. Harvard University Press. 
Linse, U. (2009). "Fundamentalistischer" Heimatschutz. Die "Naturphilosophie" Reinhard Falters. In:

U. Puschner \& U. Großmann (Eds), Völkisch und national (pp. 156-178). WBG.

Lockwood, M. (2018): Right-wing populism and the climate change agenda: exploring the linkages. Environmental Politics, DOI: 10.1080/09644016.2018.1458411.

McCright, A. M. \& Dunlap, R. E. (2011). Cool dudes: the denial of climate change among conservative white males in the United States. Global Environmental Change, 21, 1163-1172.

McKewon, E. (2012). Talking points ammo. Journalism Studies, 13(2), 277-297.

Mudde, C. (2007). Populist Radical Right Parties in Europe. Cambridge University Press.

Olsen, J. (1999). Nature and Nationalism: Right-wing Ecology and the Politics of Identity in Contemporary Germany. Palgrave.

Painter, J. \& Gavin, N. (2016). Climate skepticism in British newspapers, 2007-2011. Environmental Communication, 10(4), 432-452.

PÖ (2012). Ökologie von rechts. Braue Umweltschützer auf Stimmenfang. Oekom Verlag.

Rahmstorf, S. (2004). The climate sceptics. Potsdam: Potsdam Institute for Climate Impact Research.

Reisigl, M. \& Wodak, R. (2015). The discourse-historical approach (DHA). In: R. Wodak \& M. Meyer

(Eds), Methods of Critical Discourse Studies (pp. 23-61). Sage.

Salzborn, S. (2014). Rechtsextremismus. Nomos.

Seliger, M. (1976). Ideology and Politics. Allen and Unwin.

Smith, A. D. (1991). National Identity. University of Nevada Press.

Smith, A. D. (2009). Ethno-Symbolism and Nationalism. A Cultural Approach. Routledge.

Uekötter, F. (2006). The Green and the Brown: A History of Conservation in Nazi Germany. Cambridge University Press.

Uekötter, F. (2014). The Greenest Nation? A New History of German Environmentalism. MIT Press.

van Dijk, T. (1991). The interdisciplinary study of news as discourse. In: K. Bruhn-Jensen \& N. Jankowksi (Eds), Handbook of Qualitative Methods in Mass Communication Research (pp. 108120). Routledge. 
van Rensburg, W. (2015). Climate change skepticism: a conceptual re-evaluation. SAGE Open, 5(2), 113.

Voss, K. (2014). Nature and Nation in Harmony: The Ecological Component of Far Right Ideology. Unpublished PhD thesis. Florence. 